\title{
Foraging activity of the snail kite, Rostrhamus sociabilis (Aves: Accipitridae) in wetlands of southern Brazil
}

\author{
Bergmann, FB. ${ }^{a *}$, Amaral, HLC. ${ }^{b}$, Pinto, DP. ${ }^{a}$, Chivittz, CC. ${ }^{c}$ and Tozetti, AM. ${ }^{d}$ \\ aPrograma de Pós-graduação em Biologia de Ambientes Aquáticos Continentais, Laboratório de Ecologia de Vertebrados \\ Terrestres, Instituto de Ciências Biológicas, Universidade Federal do Rio Grande - FURG, CEP 96201-900, \\ Rio Grande, RS, Brazil \\ 'Programa de Pós-graduação em Parasitologia, Laboratório de Ecologia de Parasitos e Vetores, Instituto de Biologia, \\ Universidade Federal de Pelotas - UFPel, CEP 96010-610, Pelotas, RS, Brazil \\ 'Laboratório de Ecologia de Vertebrados Terrestres, Instituto de Ciências Biológicas, \\ Universidade Federal do Rio Grande - FURG, CEP 96201-900, Rio Grande, RS, Brazil \\ ${ }^{d}$ Universidade do Vale do Rio dos Sinos - UNISINOS, Av. Unisinos, 950, CEP 93022-000, São Leopoldo, RS, Brazil \\ *e-mail: fabiberg@yahoo.com.br \\ Received March 12, 2012 - Accepted July 27, 2012 - Distributed May 31, 2013
}

(With 2 figures)

\begin{abstract}
The snail kite (Rostrhamus sociabilis) is widely distributed in the American continent. Its specialised diet consists mostly of the gastropod mollusk Pomacea sp and its foraging strategy probably varies depending on the season, prey availability, and climate factors, which can be reflected in its semi-nomad behaviour. This study was aimed at examining the hunting strategy of the snail kite, and its association with climate factors and habitat heterogeneity. Direct observations of birds between January 2010 and March 2011 in southernmost Brazil revealed that hunting was still the predominant foraging strategy ( $79 \%$ of records) to capture mollusks. Despite morphological specialisations to extract mollusks from the shells, the handling time (average $=92.4 \mathrm{~s}$ ) was twice as much the time between prey search and capture (average $=55 \mathrm{~s}$ ). The increase in the number of mollusks ingested apparently occurs when the resting time on perches or any other substrates near the hunting sites decreases between successive unsuccessful attempts. The correlation between the number of consumed preys and the climatic variables examined was low. Regarding habitat heterogeneity, our findings suggest that birds forage preferentially in marshes with low vegetation, which may increase the access to mollusks. The hunting efficiency of the snail kite was high (76\% successful attempts) compared to those of other birds of prey.
\end{abstract}

Keywords: feeding, wetlands, predation, trophic ecology.

\section{Atividade de forrageio de gavião-caramujeiro, Rostrhamus sociabilis (Aves: Accipitridae) em áreas úmidas do sul do Brasil}

\begin{abstract}
Resumo
O gavião-caramujeiro (Rostrhamus sociabilis) possui ampla distribuição no continente americano e apresenta dieta especializada no molusco gastrópode Pomacea sp. Possivelmente, a estratégia de forrageio da espécie responde às variações sazonais na disponibilidade de presas, bem como aos fatores climáticos, o que pode refletir em seu comportamento seminômade. O objetivo desse estudo foi avaliar a estratégia de caça do gavião-caramujeiro, buscando suas associações quanto aos aspectos climáticos e à heterogeneidade do habitat. Observações diretas das aves, feitas entre janeiro de 2010 e março de 2011 no extremo sul brasileiro, revelaram que, para a captura dos moluscos, as aves usaram predominantemente a estratégia de caça do tipo still hunting (79\% dos registros). Apesar de apresentar especializações morfológicas para a extração dos moluscos da concha, a avaliação do tempo empregado na manipulação ( média $=92,4 \mathrm{~s}$ ) foi quase o dobro do desprendido entre a procura e a captura (média $=55 \mathrm{~s}$ ) das presas. Aparentemente, o aumento no número de moluscos ingeridos ocorre por meio de redução no tempo de repouso entre sucessivas investidas de captura mal sucedidas, tal como pelo uso de poleiros ou quaisquer outros substratos próximos aos locais de captura. $\mathrm{O}$ número de presas consumidas apresenta baixa relação com as variáveis climáticas testadas. Quanto à heterogeneidade do habitat, os dados sugerem que as aves forrageiam preferencialmente em banhados com cobertura vegetal rasteira, o que poderia aumentar a acessibilidade aos moluscos. O gavião-caramujeiro apresentou alta taxa de eficiência de caça (76\% das investidas tiveram êxito), revelando a eficiência da estratégia de caça desta ave quando comparada a outras aves de rapina.
\end{abstract}

Palavras-chave: alimentação, banhados, predação, ecologia trófica. 


\section{Introduction}

Birds of prey occupy the top of the trophic chain and can affect, even indirectly, the population dynamics of several species (Korpimãki, 1984). Therefore, they play an important ecological role, as they regulate prey populations and maintain regional diversity (Petty, 1998). The neotropical region is home of 170 birds of prey, most from the Accipitridae family (Stotz et al., 1996). Although many members of this family have a generalist diet (e.g. arthropods, anurans, small mammals), some have a more restrict diet, such as the snail kite [(Rostrhamus sociabilis, (Vieillot, 1817)] (Magalhães, 1990; Tanaka et al. 2006). This bird occurs from southern United States to Uruguay and has a specialised diet of gastropod mollusks, more specifically Pomacea sp. (Perry, 1811) (Tanaka et al. 2006).

Its diet specialisation is accompanied by a series of behaviours associated to the predation of aquatic invertebrates. This mollusk (Pomacea) frequently rises to the surface (Ribeiro-Costa and Rocha, 2006) when it becomes vulnerable to predation by the snail kite. To locate their prey, kites fly over water bodies (course hunting) or roost until a prey is detected and then captured in a short flight (still hunting) (Beissinger, 1983).

The use of different hunting strategies might be associated to habitat heterogeneity, such as the composition of plant cover in the foraging sites or water body depth (Sykes, 1987; Bennetts et al., 2006; Tanaka et al. 2006). Since raptors detect their prey mainly visually (Fox et al., 1976; Jones et al., 2007), habitat heterogeneity might limit their ability to locate preys while flying. Therefore, the presence of the kite in the habitat and its migratory movements might be a response to the availability of favourable foraging habitats, and not only to snail availability and abundance (Bennetts et al., 2006).

In southern Brazil, the diet of the snail kite is based on Pomacea canaliculata (Lamarck, 1822) (personal observation), a mollusk widely distributed in South America (Dillon, 2000). The activity and life cycle of this mollusk respond to environmental variables such as climate (Stevens et al., 2002; Darby et al., 2002, 2008), and consequently its availability varies seasonally to kites. Therefore, the study of hunting strategies of this species can reveal important aspects of trophic ecology of birds of prey, as well as their relationship to environmental, wind speed, rainfall and other climatic conditions. In addition, wetlands in southern Brazil are currently endangered by the advance of agricultural areas for rice, eucalyptus, pine and cattle ranching (Guadagnin and Laidner, 1999; Maltchik et al., 2003). This reinforces the need of studies on species associated to wetlands. Due to the dependence on a specific prey, we expected that the snail kite presents a more intense foraging activity in warmest and wettest months that are also more favourable for rising of temporary water bodies and for the increase of the availability of mollusks. Additionally we hypothesized that foraging activity of the snail kite is concentrated in habitats with shallower bodies of water and with a predominance of low vegetation that should facilitate the prey detection. Therefore in this study, we investigated the foraging activity of the snail kite (hunting and consumption behaviour) and its relationships with climate variable and habitat characteristics, such as water depth, type of predominant vegetation in the water bodies used for foraging, in southern Brazil.

\section{Material and Methods}

\subsection{Study site}

The study was carried out in southern Brazil, in the municipality of Rio Grande, Rio Grande do Sul state. This region encompasses the Pampa biome, characterised by an extensive area of wetlands, temporary lagoons, lakes and associated marshes (Waechter, 1985). The climate is humid subtemperate with average annual temperature and rainfall of $17.8^{\circ} \mathrm{C}$ and $1283.5 \mathrm{~mm}$, respectively (Maluf, 2000). During the study, the hottest months were January and February (average air temperature $=24.2^{\circ} \mathrm{C}$ ) and the coldest months were July and August (average air temperature $=13.1^{\circ} \mathrm{C}$ ). The total accumulated rainfall was $1654.7 \mathrm{~mm}$, with February and July as the rainiest months $(386.6 \mathrm{~mm})$ and August and October, the driest ones $(70.9 \mathrm{~mm})$. The climate data were obtained from the Embrapa Clima Temperado Climate Meteorological Station, operated by the Laboratory of Agrometeorology.

Samplings were concentrated in two marshes: "Marambaia Marsh" (31 ${ }^{\circ} 48^{\prime} \mathrm{S}$ and 52 $\left.2^{\circ} 19^{\prime} \mathrm{O}\right)$, with approximately 300 ha, and "Senandes Marsh" (32 $08^{\circ}$ S and $52^{\circ} 11^{\prime} \mathrm{O}$ ), with nearly $70 \mathrm{ha}$, both at sea level and henceforth termed Marambaia and Senandes, respectively. Non-standardised complementary records were obtained in temporary water bodies between study sites. The surroundings of both marshes consist of natural grasslands and pastures (extensive cattle ranching). The evaluation of the foraging activity of the snail kite was carried out based on direct and indirect evaluations (Figure 1).

\subsection{Sampling by direct evaluation}

This evaluation consisted of direct observations of foraging birds. Foraging behaviours were recorded according to the focal animal sampling method (Lehner, 1979), between January 2010 and March 2011. Birds were observed from an average distance of $100 \mathrm{~m}$, minimising the disturbance on the behaviour of birds. Between 8:30 AM and 11:30 AM, the banks of water bodies were walked and when a perched snail kite was observed, the bird was monitored until the commencement of a foraging bout (beginning of a flight from a perch in search of snails). To optimize sampling, when a detected individual did not begin foraging within 10 minutes, a new individual was selected. During the observations, the following behavioural units were recorded: a) hunting bout: defined as each cycle beginning with a flying bird (previously roosting) exploring the water body until its return to the perch and $b$ ) foraging bout: defined as the set of hunting bouts for the same bird. 

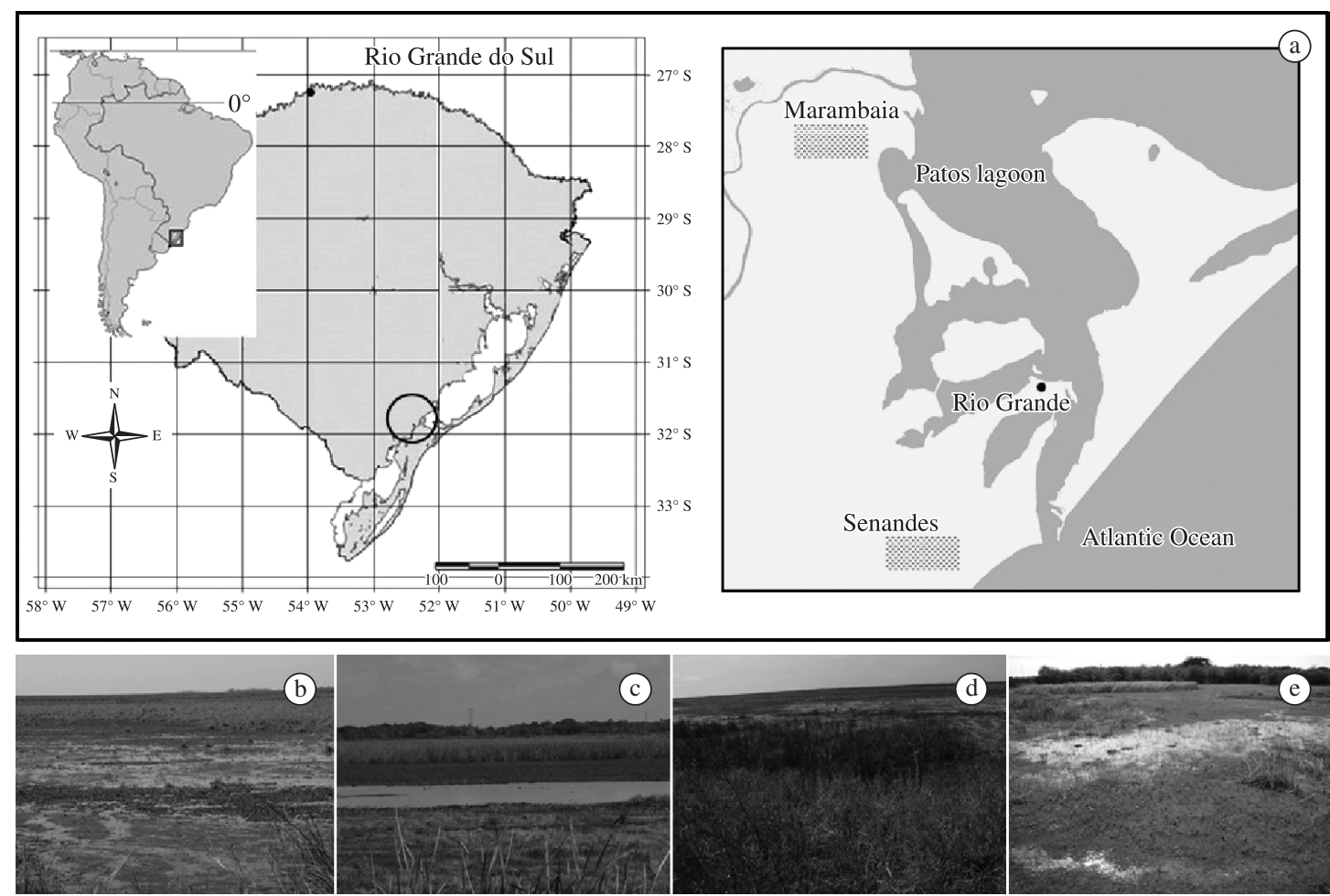

Figure 1. Geographic location of the study site (a) and general aspect of the vegetation cover (habitat matrix; b-e) in the sampled marshes.

The animals were observed until the time interval between successive hunting bouts was five minutes or the bird was out of sight from the observer. Because of the similarity between females and juveniles, the gender of animals was not determined. The foraging behaviour was evaluated based on the type of strategy used in each hunting bout, as follows: still hunting (when the kite detects the prey directly from a perch and captures it in a short flight), or course hunting (when the kite detects the prey while flying over a water body). Additionally, for each hunting bout, we recorded the duration in seconds when the animal: (a) flew over the water body searching for snails - from roosting until capturing the prey; (b) handling each captured prey - from roosting with the prey until consumption, and (c) rested after ingestion and commencement of a new hunting bout.

To examine if the birds were site specific regarding prey handling and consumption (generally termed perches), for each foraging bout, the following information was recorded: a) number and type of substrate used for prey handling (ground, pole, non-woody vegetation and/or trees or shrubs) and b) longest distance between substrates used in the set of hunting bouts of a same bird (less than $1 \mathrm{~m}$, between 1 and $5 \mathrm{~m}$, between 5 and $10 \mathrm{~m}$, and more than $10 \mathrm{~m})$.

\subsection{Sampling by indirect evaluation}

This evaluation consisted of collecting $P$. canaliculata shells accumulated after feeding and counting the number of perches used by birds. Two $200 \mathrm{~m}$ long transections were delimited in each marsh (Marambaia and Senandes) at least $1 \mathrm{~km}$ apart from each other. The location of transections was defined based on the characteristics of the terrain to facilitate finding abandoned shells and avoid areas of high vegetation or with a risk of flooding. Prior to the data collection for the indirect evaluation, all previously abandoned shells were removed. Transections were walked every two weeks between February and December of 2010, when kites were active in water bodies near transections between 8:30 AM and 11:30 AM. Shells were collected and perches were quantified. Shells were measured for operculum length, following Beissinger (1983).

\subsection{Characterisation of foraging sites}

This evaluation was carried out around the transections used for shell collecting. The habitat was characterised based on plant cover patterns and water body depth. To characterize the habitat structure within each marsh, photographs were taken at five spots along each transection ( $0 \mathrm{~m}, 50 \mathrm{~m}, 100 \mathrm{~m}, 150 \mathrm{~m}$ and $200 \mathrm{~m})$. At each spot, the photographer faced the water body and the habitat was photographed at a fixed height of $1.5 \mathrm{~m}$. To characterize the microhabitat, a 25 square screen ( 5 columns and 5 lines) was placed on each digital photograph (see Freitas et al., 2002; Bennetts et al., 2006). In each square, the vegetation covering more than $50 \%$ of the area was classified as: a) shrubby vegetation in dry soil, b) shrubby vegetation in flooded soil, c) low vegetation in dry soil, d) low vegetation 
in flooded soil, e) floating vegetation in flooded soil, and f) exposed water surface. Clusters of grasses (Juncus and Poacea) were considered shrubby vegetation, while low vegetation was defined as vegetation that on average did not exceed $30 \mathrm{~cm}$ in height. Because of the little temporal variation in plant cover pattern, this evaluation was conducted only once during the study. Measurements of water body depth were taken monthly during the indirect evaluation (February to December 2010), with a graded ruler in centimeters at three defined spots $(0 \mathrm{~m}, 100 \mathrm{~m}$ and $200 \mathrm{~m}$ ) along transections and approximately one meter from the margin of the water body.

\subsection{Data analysis}

The foraging activity was analysed based on the following parameters: (a) accumulation of shells per perch $($ shell $/$ perch $)=$ number of accumulated shells divided by the number of perches used; (b) number of accumulated shells, and (c) number of perches used. For the direct evaluation, we used the climatic variables for the days when the direct observations were performed, while for the indirect evaluation, mean air temperature and mean wind speed of the interval of days between field trips were used. Accumulated rainfall was calculated based on the sum of accumulated rainfall during the interval of days between field trips. The number of accumulated shells and number of used perches were compared among seasons of the year with an analysis of variance of Kruskal-Wallis, and when necessary, followed by a post hoc test (Zar, 1999). Differences between resting time after a successful and unsuccessful hunting bout and the comparison of the accumulation of shells per perch between the two marshes were conducted with a Mann-Whitney test (U test; Zar, 1999). The analyses were performed with the software Statistica 8.0.

The correlations among hunting strategies, number of shells accumulated, and number of successful hunting attempts and climate variables were carried out with a multiple linear regression (Hair et al., 2005). Since the number of accumulated shells in Marambaia $(\mathrm{n}=392)$ and Senandes $(n=62)$ was different, a random subsample of 62 shells were obtained from the Marambaia dataset and analysed with a t-test with samples of Senandes to compare the average size of the operculum of shells of marshes (see Ceolin and Miotto, 2011). This test was repeated 500 times and the analyses were performed with the software R.

The number of obtained and expected records for each hunting strategy, types of substrates used for prey handling, and longest distance among substrates for handling were compared with a chi-square test with Yates correction when necessary. This test was carried out with the software BioEstat 5.0. For all analysis, significance was set at $\mathrm{p}<0.05$ (Zar, 1999). Habitat characterization in the two marshes was carried out with a principal component analysis (PCA; Manly, 2008), with the software MVSP (Kovach, 1999).

\section{Results}

\subsection{Direct evaluation}

The behaviour of snail kites was observed during 65 days of monitoring, totaling 91 hours of observation (average $=84$ minutes/day). We observed 72 foraging bouts and 114 hunting bouts (average $1.58 \pm 0.93$ hunting bouts per bird).

Still hunting was more frequently observed (90 records; $79.0 \%$ of total bouts) than course hunting ( 24 records; $21 \%$ of total bouts) $\left(X^{2}=33.5 ; \mathrm{gl}=1 ; \mathrm{p}<0.0001\right.$; Yates correction $=32.49$ ). The multiple linear regression revealed that average air temperature, rainfall, and wind speed did not influence significantly the strategies still hunting $\left(\mathrm{p}>0.05 ; \mathrm{R}^{2}=0.03\right)$ or course hunting $\left(\mathrm{p}>0.05 ; \mathrm{R}^{2}=0.02\right)$.

The average time spent course hunting for snails was $55 \mathrm{~s} \pm 64.3 \mathrm{~s}$, while birds spent almost twice as much manipulating each captured prey $(92.4 \mathrm{~s} ; \pm 59 \mathrm{~s})$. The average time birds spent resting after ingestion and beginning of a new hunting bout varied according to their efficiency. On average, birds spent more time resting after a successful hunting bout $(240 \mathrm{~s} \pm 101.9 \mathrm{~s})$ than after being unsuccessful (141 s $\pm 147.3 \mathrm{~s} ; \mathrm{U}=301.0 ; \mathrm{p}<0.05 ; \mathrm{n}=71$ ).

The evaluation of hunting efficiency was based on 71 records of hunting bouts, from which 54 (76\%) were successful and 17 (24\%) kites were not able to remove the prey from the water body or it was lost on flight after capture. The linear multiple regression indicated that the number of successful hunting bouts was not significantly correlated with average air temperature, rainfall, and wind speed $\left(\mathrm{p}>0.005 ; \mathrm{R}^{2}=0.02\right)$.

Captured prey were predominantly handled on the ground ( $45.6 \%$ of 125 records), followed by the use of non-natural perches, such as poles (40\% of records) $\left(X^{2}=52.1 ; \mathrm{gl}=3 ; \mathrm{p}<0.0001\right)$, non-woody and/or shrubby vegetation (10.4\% of records) and trees ( $4 \%$ of records). In the consecutive hunting bouts, kites used predominantly the same substrates or those closer from each other $\left(X^{2}=37.7\right.$; $\mathrm{gl}=3 ; \mathrm{p}<0.0001$ ), with a distance between then less than $1 \mathrm{~m}$ in $50 \%$ of the foraging bouts, between 1 and $5 \mathrm{~m}$ in $13.9 \%$, between 5 and $10 \mathrm{~m}$ in $11.1 \%$, and more than $10 \mathrm{~m}$ in $25 \%$ of the foraging bouts.

\subsection{Indirect evaluation}

The number of accumulated shells varied significantly among the seasons of the year. Shells were more abundant in the summer ( 557 shells) than in the fall (15 shells) or winter (12 shells) (Table 1; $\mathrm{H}_{[3,38]}=17.77 ; \mathrm{p}<0.001 ; \mathrm{n}=38$ ). The linear multiple regression revealed that average air temperature, rainfall, and wind speed influenced significantly the number of accumulated shells (Table $1 ; \mathrm{H}_{[3,38]}=17.77$; $\mathrm{p}<0.001 ; \mathrm{n}=38$ ). Average air temperature was positively correlated to number of accumulated shells $(\mathrm{p}<0.05)$, while rainfall $(\mathrm{p}>0.05)$ and wind speed $(\mathrm{p}>0.05)$ were not significantly associated.

Operculum length varied significantly between the two marshes (t-test; $p<0.05)$. In Marambaia, the 
Table 1. Parameters calculated for the evaluation of the foraging activity of the snail kite (Rostrhamus sociabilis) in two marshes of southernmost Brazil, between February and December 2010.

\begin{tabular}{|c|c|c|c|c|c|}
\hline Marsh & Season & $\begin{array}{l}\text { Average of the interval of } \\
\text { days of samplings }( \pm \mathrm{DP})\end{array}$ & $\begin{array}{l}\text { Number of } \\
\text { accumulated } \\
\text { shells }\end{array}$ & $\begin{array}{c}\text { Number of } \\
\text { used perches }\end{array}$ & $\begin{array}{c}\text { Accumulation } \\
\text { of shells per } \\
\text { perch }\end{array}$ \\
\hline \multirow[t]{6}{*}{ Marambaia } & Summer & $15.67( \pm 1.15)$ & 481 & 70 & 6.87 \\
\hline & Fall & $15.17( \pm 3.25)$ & 15 & 7 & 2.14 \\
\hline & Winter & $17.40( \pm 1.52)$ & 2 & 1 & 2.00 \\
\hline & Spring & $14.80( \pm 1.48)$ & 56 & 14 & 4.00 \\
\hline & Total & - & 554 & 92 & - \\
\hline & Average & $15.74( \pm 2.28)$ & - & - & 6.02 \\
\hline \multirow[t]{6}{*}{ Senandes } & Summer & $14.25( \pm 2.22)$ & 76 & 17 & 4.47 \\
\hline & Fall & $15.50( \pm 2.81)$ & 0 & 0 & 0 \\
\hline & Winter & $16.60( \pm 4.16)$ & 10 & 1 & 10.00 \\
\hline & Spring & $19.00( \pm 2.16)$ & 22 & 7 & 3.14 \\
\hline & Total & - & 108 & 25 & - \\
\hline & Average & $16.26( \pm 3.23)$ & - & - & 4.32 \\
\hline \multirow[t]{6}{*}{ Marambaia + Senandes } & Summer & $14.86( \pm 1.86)$ & 557 & 87 & 6.40 \\
\hline & Fall & $15.33( \pm 2.90)$ & 15 & 7 & 2.14 \\
\hline & Winter & $17( \pm 2.98)$ & 12 & 2 & 6 \\
\hline & Spring & $16.67( \pm 2.78)$ & 78 & 21 & 3.71 \\
\hline & Total & - & 662 & 117 & - \\
\hline & Average & $16.00( \pm 2.77)$ & - & - & 5.66 \\
\hline
\end{tabular}

average operculum size was $3.3 \mathrm{~cm}(\mathrm{n}=392 ; \pm 0.7$ range $=1.5-5.1 \mathrm{~cm})$ while in Senandes, $3.7(\mathrm{n}=62 ; \pm 0.7$ range $=2.0-5.4 \mathrm{~cm})$.

In the summer, kites used more perches in both marshes $\left(\right.$ Marambaia $=70 ;$ Senandes $=17 ;$ Table $1 ; \mathrm{H}_{[3,38]}=18.66$; $\mathrm{p}<0.05 ; \mathrm{n}=38$ ). The a posteriori test revealed significant differences between summer and fall, and summer and winter.

The accumulation of shells per perch was not significantly different between Marambaia (6.02 shells/perch) and Senandes (4.32 shells/perch ; Table 1; $U=175$. 00; $\mathrm{p}>0.05 ; \mathrm{n}=38)$.

\subsection{Characterization of the foraging areas}

The PCA revealed that most of the variation of the characteristics between the two foraging areas indirectly monitored was explained by the two first axes (approximately $68.1 \%$ of the variation; Table 2,3 ). The vectors indicate the increase the relationship between the characteristics examined. In general, the spots sampled in Marambaia revealed an association with a larger set of different variables, suggesting that this marsh is structurally more heterogeneous than Senandes. In Marambaia, nonflooded areas of the habitat exhibit more association with shrubby vegetation (SHV), while flooded portions are predominantly characterized by low vegetation (LOV) (Figure 2). Conversely, in Senandes, the non-flooded portions of the habitat have stronger associations with low vegetation (LOV) and more extensive areas with exposed water surface (EWS) (Figure 2).
Table 2. Eigenvalues and percentage of variance explained by the three principal components (axes 1 to 3 ) of the variation in characteristics in the marshes Marambaia and Senandes: a) Shrubby vegetation in dry soil, b) Shrubby vegetation in flooded soil, c) Low vegetation in dry soil, d) Low vegetation in flooded soil, e) Floating vegetation, f) Exposed water surface and g) Water body depth.

\begin{tabular}{lccc}
\hline & Axis 1 & Axis 2 & Axis 3 \\
\hline Eigenvalue & 2.746 & 1.429 & 0.903 \\
Percentage & 42.775 & 23.3 & 14.717 \\
Cumulative \% & 41.775 & 68.075 & 82.793 \\
\hline
\end{tabular}

Table 3. Eigenvalues of the three principal components (axes 1 to 3 ) of the variation in the characteristics in the marshes Marambaia and Senandes: SVD $=$ Shrubby vegetation in dry soil, SVF = Shrubby vegetation in flooded soil, LVD $=$ Low vegetation in dry soil, $\mathrm{LOV}=$ Low vegetation in flooded soil, FV = Floating vegetation, EWS = Exposed water surface, $\mathrm{WBD}=$ Water body depth.

\begin{tabular}{lrrr}
\hline & Axis 1 & Axis 2 & Axis 3 \\
\hline SVF & -0.303 & 0.405 & -0.636 \\
LVF & 0.341 & -0.662 & -0.078 \\
FV & 0.471 & 0.538 & 0.245 \\
SVD & 0.389 & -0.133 & -0.182 \\
LVD & -0.257 & 0.095 & 0.689 \\
EWS & -0.594 & -0.286 & 0.057 \\
WBD & -0.003 & -0.008 & -0.133 \\
\hline
\end{tabular}




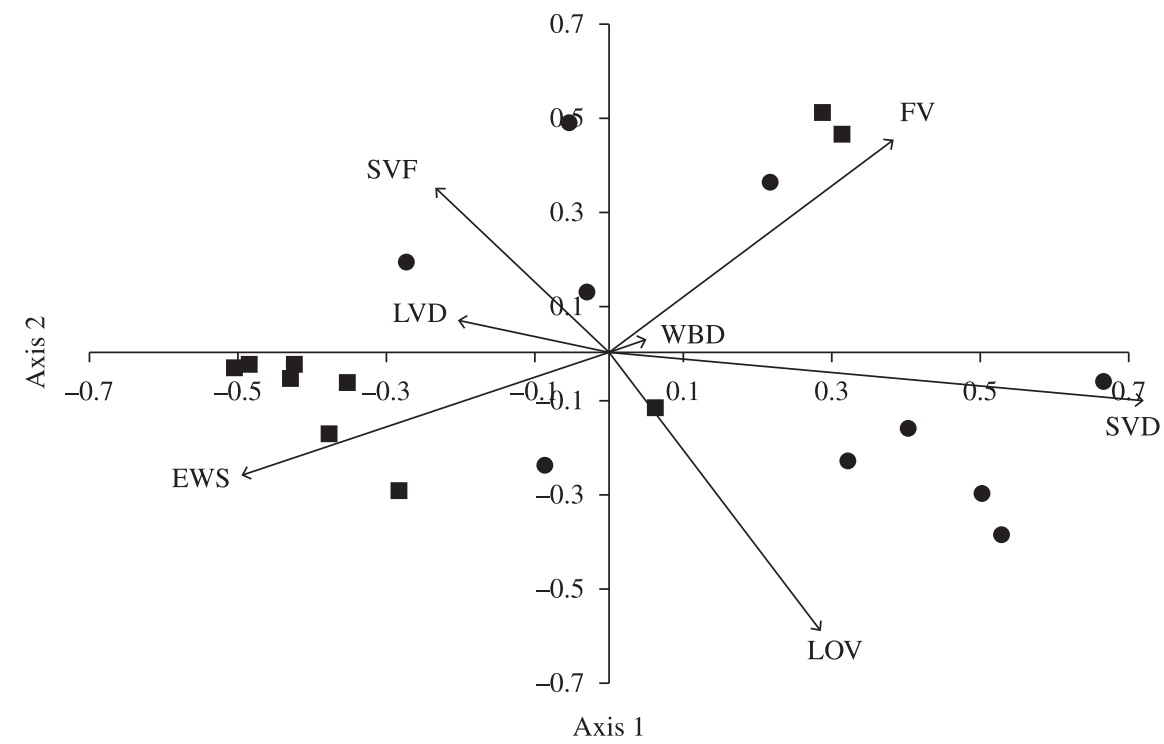

Figure 2. Ordination diagram ("biplot") of the samples along $1^{\circ}$ (vertical) and $2^{\circ}$ (horizontal) axes of the Principal Component Analysis (PCA), generated from the analysis of seven classifications of characteristics of Marambaia and Senandes. Variable vectors of the classifications of the foraging sites: SVD = Shrubby vegetation in dry soil, SVF = Shrubby vegetation in flooded soil, $\mathrm{LVD}=$ Low vegetation in dry soil, $\mathrm{LOV}=$ Low vegetation in flooded soil, FV = Floating vegetation, EWS $=$ Exposed water surface, $\mathrm{WBD}=$ Water body depth. Circle $=$ Marambaia and Square $=$ Senandes.

\section{Discussion}

\subsection{Direct evaluation}

The strategy still hunting may be more frequently used due to a predominance of low vegetation. The pattern of plant cover can affect the access of kites to snails. In water bodies with very dense vegetation, course hunting might become more common. We expected that in days with stronger winds, kites could more easily fly over the marsh and in these conditions the strategy course hunting would be more frequently observed. However, this was not observed, and no associations were found between hunting strategies and the climate variables examined. These data suggest that prey-capture success is little affected by climate and rather predominantly by plant cover.

The time spent during prey handling is approximately 2.5 times more than that of search, suggesting that snails are relatively easily detected and captured. In addition, the resting time is shorter after an unsuccessful hunting bout, which might be an attempt to compensate the time lost. This might explain the use of several types of substrate by birds. Given the longer handling time in relation to that of capture, handling begins soon after capture.

Birds were successful in $76.1 \%$ of hunting attempts, similar to the reported in other studies for this species: $78 \%$ in wetlands of Guiana (Beissinger, 1983) and $84 \%$ in the Brazilian Pantanal (Magalhães, 1990). In general, the snail kite had a high success rate when compared to other birds of prey: 6\% for Accipiter gentilis (Linnaeus, 1758) (Kenward, 1982), up to $15.1 \%$ for Circus cyaneus (Linnaeus, 1766) (Collopy and Bildstein, 1987) and 24\% for Aquila pomarina (Brehm, 1831) (Mirski, 2010). This high efficiency is in part associated to the fewer defense strategies and less mobility of the mollusk as the prey of $R$. sociabilis, compared to arthropods, anurans, rodents hunted by these other raptors.

Our results revealed that the snail kite can use several types of substrates (e.g. ground, vegetation), contrary to studies reporting the exclusive use of perches for prey handling (Collet, 1977; Tanaka et al., 2006). The use of several substrates may be an attempt to reduce the time between capture of the snail and the beginning of handling, since this was identified as the longest step in the feeding process. The short movements from the initial handling site and repeating hunting bouts suggest a fidelity to the former.

\subsection{Indirect evaluation}

At the study site, snail kites are more abundant in the warmer months (Chivittz et al., 2011), which can influence the number of shells accumulated throughout the year. This variation might be a response to an increase in activity of P. canaliculata during this period (Estebenet and Martín, 2002), and consequently becoming more accessible to birds. Thus it explains the higher number of accumulated shells and perches used in the summer. The relationship between presence of kites and availability of Pomacea has been reported in other studies (Stevens et al., 2002).

The lack of a correlation between foraging activity, rainfall, and wind speed can be due to the little variation of these climate factors during the study. In addition, the need to feed may overcome possible difficulties imposed by winds and rains. 
The size of shells of consumed snails found in the two marshes was very similar and within the size range reported in other studies: 4.6-5.8 cm reported by Estela and Naranjo (2005), 4-5.5 cm in Tanaka et al. (2006) and 4-4.5 cm in Mapelli and Kittlein (2011). This suggests a selectivity regarding snail size. This process might have a cost-benefit relationship between capture and handling, since large snails are difficult for birds to manipulate and often slip from talons (Snyder and Kale, 1983) and are lost, wasting the bird's time and energy. Conversely, small snails are captured and handled awkwardly, as this bird has relatively large talons and are probably adequate to a range of shell size. Also, this adjustment of optimum shell size might involve learning by young birds (based on Collett, 1977; Magalhães, 1990) and this selection might contribute for higher success rates in captures. Therefore, the long handling times or little energy gain might not be advantageous when capturing very large or very small shells, respectively (MacArthur and Pianka, 1966).

Although the two foraging sites examined did not differ significantly regarding the number of perches or accumulated shells, there was a tendency to less foraging activity in Senandes. Snail kites are semi-nomads and might have biased the sampling if birds moved to areas farther from the transections, minimizing the probability of data collection. As a result, the wide variation regarding the incidence of these birds made the detection of patterns difficult. However, the total of shells accumulated in Marambaia was higher than in Senandes (approximately fivefold).

Also, PCA revealed important differences in habitat heterogeneity between the two foraging sites. In general, the spots sampled in Marambaia revealed a higher heterogeneity regarding plant cover, in dry as well as flooded areas than in Senandes. In Marambaia, non-flooded areas of the habitat had a stronger association with shrubs, while flooded portions had predominantly low vegetation. These characteristics might facilitate the visualisation of snails by birds during flights, as portions of the habitat composed of tall or dense vegetation can obstruct the vision of snail kites or even prevent their access to snails due to its lack of ability to descend to the water surface in these conditions (Beissinger, 1983; Bennetts et al., 2006). On the other hand, in Senandes, the low vegetation is concentrated in the non-flooded areas of the habitat, with lower probability of snails. In addition, in this foraging site, a predominance of more extensive areas with exposed water was observed. These areas might be avoided by snails, as they would be more exposed or have a lower carrying capacity (less resources for herbivorous invertebrates such as Pomacea; Cazzaniga and Estebenet, 1984).

Our findings suggest that aspects of the habitat such as plant cover and the type of water surface can interfere in the availability or access of snails to kites. Also, these characteristics seem to be more important than climate variables for the foraging activity of this bird. The seminomad behaviour of this species might result in the search for regions of the habitat with better foraging conditions.
Acknowledgements - The authors acknowledge the collaboration of Dr. D.L. Guadagnin (Universidade Federal do Rio Grande do Sul - UFRGS), Dr. L. Bugoni (Universidade Federal do Rio Grande - FURG), Mr. A. G. Sacco, Dra. E. F. Albertoni (FURG), Dr. G. Ceolin (FURG) and the Taim Ecological Station and the logistical support offered from the FURG. The study was possible with the financial support of CAPES and CNPq.

\section{References}

BEISSINGER, SR., 1983. Hunting behavior, prey selection, and energetics of snail kites in Guyana. Auk, vol. 100, p. 84-92.

BENNETTS, RE., DARBY, PC. and KARUNARATNE, LB., 2006. Foraging patch selection by Snail Kites in response to vegetation structure and prey abundance and availability. Waterbirds, vol. 29, no. 1, p. 88-94. http://dx.doi.org/10.1675/15244695(2006)29[88:FPSBSK]2.0.CO;2

CAZZANIGA, NJ. and ESTEBENET, AL. 1984. Revision y notas sobre los habitos alimentarios de los Ampullariidae (Gastropoda). Historia Natural, vol. 4, no. 22, p. 213-224.

CEOLIN, GB. and MIOTTO, STS., 2011. Combining ecological and morphometrical approaches to increase the resolution within the Galactia neesii (Leguninosae) complex. Plant Systematics and Evolution. In press. http://dx.doi.org/10.1007/s00606-011-0573-5

COLLET, SF., 1977. Sizes of snails eaten by Snail Kites and Limpkins in a Costa Rican marsh. Auk, vol. 94, no. 2, p. 365-367.

COLLOPY, MW. and BILDSTEIN, KL., 1987. Foraging behavior of Northern Harriers wintering in southeastern salt and freshwater marshes. Auk, vol. 104, no. 1, p. 11-16. http://dx.doi. org/10.2307/4087227

CHIVITTZ, CC., PINTO, DP., BERGMANN, FB. and TOZETTI, AM., 2011. Atividade sazonal de forrageamento de Rostrhamus sociabilis (Aves: Accipitridae) em áreas de banhado no extremo sul brasileiro. In Anais X Congresso de Ecologia do Brasil, 2011. São Lourenço: Minas Gerais.

DARBY, PC., BENNETTS, RE., STEVEN, JM. and PERCIVAL, HF., 2002. Movements of Florida Apple Snail in relation to water levels and drying events. Wetlands, vol. 22, no. 3, p. 489-498. http://dx.doi.org/10.1672/0277-5212(2002)022[0489:MOFAS I] $2.0 . \mathrm{CO} ; 2$

DARBY, PC., BENNETTS, RE. and PERCIVAL, HF., 2008. Dry down impacts on Apple Snail (Pomacea paludosa) demography: Implications for wetland water management. Wetlands, vol. 28, no. 1, p. 204-214. http://dx.doi.org/10.1672/07-115.1

DILLON, RT., 2000. The ecology of freshwater molluscs. Cambridge: Cambrige University Press. p. 509. http://dx.doi. org/10.1017/CBO9780511542008

ESTEBENET, AL. and MARTÍN, PR., 2002. Pomacea canaliculata (Gastropoda: Ampullariidae): life-history traits and their plasticity. Biocell, vol. 26, no. 1, p. 83-89. PMid:12058384.

ESTELA, FA. and NARANJO, LG., 2005. Segregación em el tamano de caracoles depredados por el gavilán caracolero (Rostrhamus sociabilis) y el carrao (Aramus guarauna) em el suroccidente de Colombia. Ornitologia Colombiana, vol. 3, p. 36-41.

FOX, R., STEPHEN, W., LEHMKUHLE, SW. and WESTENDORF, DH., 1976. Falcon visual acuity. Science, vol. 192, no. 4236, p. 263-265. http://dx.doi.org/10.1126/science. 1257767 
FREITAS, SR., CERQUEIRA, R. and VIEIRA, MV., 2002. A device and standard variables to describe microhabitat structure of small mammals based on plant cover. Brazilian Journal of Biology, vol. 62, no. 4b, p. 795-800. PMid:12659030.

GUADAGNIN, DL. and LAIDNER, C., 1999. Diagnóstico da Situação e Ações Prioritárias para a Conservação da Zona Costeira da Região Sul - Rio Grande do sul e Santa Catarina. Pronabio. Funbio. Porto Alegre. p. 91. Avaliação e Ações Prioritárias para a Conservação da Biodiversidade da Zona Costeira e Marinha. Available from: <www.bdt.org.br/workshop/costa $>$.

HAIR, FJ., ANDERSON, RE., TATHAM, RL. and BLACK, WC., 2005. Análise Multivariada de dados. Porto Alegre: Bookman. p. 600.

JONES, MP., PIERCE, KE. and WARD, D., 2007. Avian vision: A review of form and function with special consideration to birds of prey. Journal Exotic Pet Medicine, vol. 16, no. 2, p. 69-87. http://dx.doi.org/10.1053/j.jepm.2007.03.012

KENWARD, RE., 1982. Goshawk hunting behavior, and range size as a function of food and habitat availability. Journal of Animal Ecology, vol. 51, no.1, p. 69-80. http://dx.doi.org/10.2307/4311

KORPIMÃKI, E., 1984. Population dynamics of birds of prey in relation to fluctuations in small mammal populations in western Finland. Annales Botanici Fennici, no. 21, p. 287-293.

KOVACH, WL., 1999. MVSP - A multi-variate statistical package for Windows. ver. 3.1. Penthraeth: Kovach computing Services.

LEHNER, PN., 1979. Handbook of ethological methods. New York: Garland Press. p. 403.

MacARTHUR, RH. and PIANKA, ER., 1966. On optimal use of a patchy environment. The American Naturalist, vol. 100, no. 916, p. 603-609. http://dx.doi.org/10.1086/282454

MALTCHIK, L., COSTA, ES., BECKER, CG. and OLIVEIRA, AE., 2003. Inventory of wetlands of Rio Grande do Sul (Brazil). Pesquisas Botânicas, vol. 53, p. 89-100.

MALUF, JRT., 2000. Nova classificação climática do Estado do Rio Grande do Sul. Revista Brasileira de Meteorologia, vol. 8, no. 1 , p. 141-150.

MAGALHÃES, CA., 1990. Hábitos alimentares e estratégia de forrageamento de Rostrhamus sociabilis no Pantanal de Mato Grosso, Brasil. Ararajuba, vol. 1, p. 95-98.
MANLY, BFJ., 2008. Métodos Estatísticos Multivariados: Uma introdução. 3rd ed. Porto Alegre: Bookman. p. 229.

MAPELLI, FJ. and KITTLEIN, MJ., 2011. Prey selection by the Snail Kite (Rostrhamus sociabilis) in permanent and temporary wetlands of Central Argentina. Ornitologia Neotropical, vol. 22, p. 281-293.

MIRSKI, P., 2010. Effect of Selected Environmental Factors on Hunting Methods and Hunting Success in the Lesser Spotted Eagle Aquila pomarina in North Eastern Poland. Russian Journal of Ecology, vol. 41, no. 2, p. 197-200. http://dx.doi.org/10.1134/ S1067413610020165

STOTZ, DF., FITZPATRICK, JW., PARKER III, TA. and MOSKOVITS, DK., 1996. Neotropical Birds: Ecology and Conservation. Chicago: University Chicago Press. p. 506.

PETTY, SJ., 1998. Ecology and Conservation of Raptors in Forests. Forestry Commision. Bulletin 118. London: The Stationary Office. p. 56.

RIBEIRO-COSTA, CS. and ROCHA, RM., 2006. Invertebrados: Manual de aulas práticas. 2rd ed. Ribeirão Preto: Holos. p. 271.

SNYDER, NFR. and KALE, HW., 1983. Mollusk predation by snail kites in Colombia. Auk, vol. 100, p. 93-97.

SYKES, PW-Jr., 1987. The feeding habits of the Snail Kite in Florida, USA. Colon Waterbirds, vol. 10, no. 1, p. 84-92.

STEVENS, AJ., WELCH, ZC., DARBY, PC. and PERCIVAL, HF., 2002. Temperatura effects in Florida apple snail activity: implications for snail kite foraging success and distribution. Wildlife Society Bulletin, vol. 30, no. 1, p. 75-81.

TANAKA, MO., SOUZA, ALT. and MÓDENA, ES., 2006. Habitat structure effects on size selection of snail kites (Rostrhamus sociabilis) and limpkins (Aramus guarauna) when feeding on apple snails (Pomacea spp.). Acta Oecologica, vol. 30, no. 1, p. 88-96. http://dx.doi.org/10.1016/j.actao.2006.02.003

WAECHTER, JL., 1985. Aspectos ecológicos da vegetação de restinga no Rio Grande do Sul, Brasil. Comunicações do Museu de Ciências da PUCRS, Série Botânica, vol. 33, p. 49-68.

ZAR, JH., 1999. Biostatistical analysis. Englewood Cliffs: Prentice-Hall. p. 663. 